\title{
Pengaruh Pembiayaan Jual Beli, Pembiayaan Bagi Hasil, dan Rasio Non Performing Financing terhadap Profitabilitas Bank Umum Syariah di Indonesia
}

\author{
Aulia Fuad Rahman \\ Ridha Rochmanika \\ Fakultas Ekonomi dan Bisnis Universitas Brawijaya
}

\begin{abstract}
This paper examines how trade and profit-loss sharing (PLS) financing as well as non performing financing (NPF) affect theprofitability ofIslamic banking in Indonesia. The profitability is measured by return on assets. The sample selection method is purposive sampling and obtained four Islamic banks are being sampled, that is Bank Syariah Mega Indonesia, Bank Syariah Mandiri, Bank Muamalat Indonesia, and BRI Syariah in 11 periods of observation.Multiple regression is used toanalyzethe data. The resultshows thattrade financingand NPF have positivelly affect,while profit-loss sharing financing has negativelly affect on theprofitability ofIslamic banks.
\end{abstract}

Keywords: Trade financing, profit-loss sharing financing, non performing financing, profitability, return on assets (ROA).

\section{PENDAHULUAN}

Persaingan antar bank syariah yang semakin ketat, secara langsung ataupun tidak langsung, akan berpengaruh terhadap pencapaian profitabilitas bank syariah. Meskipun bank syariah memiliki motivasi lebih daripada sekedar bisnis, keamampuan bank syariah dalam menghasilkan profit menjadi indikator penting keberlanjutan entitas bisnis. Selain itu, kemampuan menghasilkan profit menjadi indikator penting untuk mengukur kemampuan bersaing bank syariah dalam jangka panjang.

Bank syariah yang berfungsi sebagai lembaga intermediasi keuangan, melaksanakan kegiatan operasionalnya dengan menghimpun dana dari masyarakat dan kemudian menyalurkannya kembali kepada masyarakat melalui pembiayaan. Dana yang dihimpun dari masyarakat biasanya disimpan dalam bentuk giro, tabungan dan deposito baik dengan prinsip wadiah maupun prinsip mudharabah. Sedangkan penyaluran dana dilakukan oleh bank syariah melalui pembiayaan dengan empat pola penyaluran yaitu prinsip jual beli, prinsip bagi hasil, prinsip ujroh dan akad pelengkap (Karim, 2008).

Penilaian kelayakan pembiayaan pada bank syariah, selain didasarkan pada business wise, juga harus mempertimbangkan syariah wise. Artinya, bisnis tersebut layak dibiayai dari segi usahanya dan acceptable dari segi syariahnya (Muhammad, 2005). Diantara empat pola penyaluran pembiayaan yang ada pada bank syariah, terdapat dua pola utama yang saat ini dijalankan oleh bank dalam penyaluran pembiayaan, yakni pembiayaan dengan prinsip jual beli dan pembiayaan dengan prinsip bagi hasil. Pendapatan bank sangat ditentukan oleh berapa banyak keuntungan yang diterima dari pembiyaan yang disalurkan. Keuntungan yang diterima dari prinsip jual beli berasal dari mark up yang ditentukan berdasarkan kesepakatan antara bank dengan nasabah. Sedangkan pendapatan dari prinsip bagi hasil ditentukan berdasarkan kesepakatan besarnya nisbah, keuntungan bank tergantung pada keuntungan nasabah. Pola bagi hasil banyak mengandung risiko, oleh karena itu pihak bank harus aktif 
berusaha mengantisipasi kemungkinan terjadinya kerugian nasabah sejak awal (Muhammad, 2005).

Harahap et al. (2005) menyebutkan bahwa akad yang banyak digunakan dalam pembiayaan pada prinsip jual beli adalah murabahah, salam dan istishna'. Sedangkan pada prinsip bagi hasil, akad yang banyak digunakan adalah mudharabah dan musyarakah. Berdasarkan statistik Bank Indonesia, akad murabahah mendominasi pembiayaan yang disalurkan bank syariah dan disusul dengan akad mudharabah dan musyarakah. Dengan diperolehnya pendapatan dari pembiayaan yang disalurkan, diharapkan profitabilitas bank akan membaik, yang tercermin dari perolehan laba yang meningkat (Firdaus, 2009). Oleh karena itu, pengelolaan pembiayaan baik pembiayaan jual beli, pembiayaan bagi hasil, maupun jenis pembiyaan lainnya akan sangat mempengaruhi profitabilitas yang diterima bank syariah.

Pembiayaan yang disalurkan oleh bank syariah dapat menimbulkan potensi pembiayaan bermasalah. Pembiayaan bermasalah dapat dilihat dari tingkat non performing financing (NPF). Menurut Siamat (2005), pembiayaan bermasalah adalah pinjaman yang mengalami kesulitan pelunasan akibat adanya faktor kesengajaan dan atau karena faktor eksternal diluar kemampuan/kendali nasabah peminjam. Jadi,besar kecilnya NPF ini menunjukkan kinerja suatu bank dalam pengelolaan dana yang disalurkan. Apabila porsi pembiayaan bermasalah membesar, maka hal tersebut pada akhirnya menurunkan besaran pendapatan yang diperoleh bank (Ali, 2004). Sehingga pada akhirnya akan dapat mempengaruhi tingkat profitabilitas bank syariah. Penelitian ini bertujuan untuk memberikan bukti empiris mengenai pengaruh pembiayaan jual beli, pembiayaan bagi hasil, dan rasionon performing financing terhadap profitabilitas Bank Umum Syariah di Indonesia.

\section{LITERATUR RIVIEW}

\section{Bank Syariah}

Berdasarkan Undang-Undang Republik Indonesia No. 21 tahun 2008 tentang Perbankan Syariah, definisi bank adalah badan usaha yang menghimpun dana dari masyarakat dalam bentuk simpanan dan menyalurkannya kepada masyarakat dalam bentuk kredit dan/atau bentuk lainnya dalam rangka meningkatkan taraf hidup rakyat. Sedangkan bank syariah adalah bank yang menjalankan kegiatan usahanya berdasarkan prinsip syariah.Fungsi dari bank syariah sesuai dengan UU No. 21 Tahun 2008 dan Wiroso (2005) adalah fungsi sosial dalam bentuk lembaga baitul mal, fungsi jasa keuangan perbankan dengan menghimpun dan menyalurkan dana masyarakat sesuai dengan prinsip-prinsip syariah, fungsi sebagai manajer investasi atas dana yang dihimpun dari pemiliki dana, serta fungsi sebagai investor dalam penyaluran dana baik dalam prinsip bagi hasil, prinsip ujroh, maupun prinsip jual beli.

Wiroso(2005) menyatakan bahwa bank syariah sebagai lembaga intermediasi melaksanakan kegiatan operasionalnya dengan menghimpunan dana dari masyarakat melalui dua prinsip yaitu prinsip wadiah yad dhamanahdan prinsip mudharabah mutlaqah. Kemudian dana bank syariah yang dihimpun disalurkan dengan pola-pola penyaluran dana yang dibenarkan syariah. Secara garis besar, penyaluran dana bank syariah dalam bentuk pembiayaan dilakukan dengan tiga pola yaitu prinsip jual beli, prinsip bagi hasil dan prinsip ujroh. Atas penyaluran dana dalam bentukpembiyaaan, bank syariah akan memperoleh pendapatan yaitu dalam prinsip jual beli lazim disebut dengan margin atau keuntungan, dan prinsip bagi hasil akan menghasilkan bagi hasil usaha, serta dalam prinsip ujroh akan memperoleh upah (sewa). Pendapatan dari penyaluran dana ini disebut dengan pendapatan operasi utama yang merupakan pendapatan yang akan dibagi hasilkan, pendapatan yang merupakan unsur perhitungan distribusi bagi hasil.Bank syariah memperoleh pendapatan operasi lainnya yang berasal dari pendapatan jasa perbankan yang merupakan pendapatan sepenuhnya miliki bank syariah. 


\section{Profitabilitas}

Profitabilitas merupakan dasar dari adanya keterkaitan antara efisiensi operasional dengan kualitas jasa yang dihasilkan oleh suatu bank.Tujuan analisis profitabilitas sebuah bank adalah untuk mengukur tingkat efisiensi usaha yang dicapai oleh bank yang bersangkutan (Kuncoro, 2002). Menurut Weygandt et al. (2008), rasio profitabilitas adalah rasio yang digunakan untuk mengukur efektivitas manajemen perusahaan secara keseluruhan, yang ditunjukkan dengan besarnya laba yang diperoleh perusahaan.

Return on Asset (ROA) merupakan salah satu rasio profitabilitas. Kuncoro (2002) menyatakan bahwa ROA menunjukkan kemampuan manajemen bank dalam mengelola aktiva yang tersedia untuk mendapatkan net income. Sedangkan Siamat (2005) mengemukakan bahwa ROA merupakan rasio yang memberikan informasi seberapa efisien suatu bank dalam melakukan kegiatan usahanya, karena rasio ini mengindikasikan seberapa besar keuntungan yang dapat diperoleh rata-rata terhadap setiap rupiah asetnya.Semakin besar ROA menunjukkan kinerja perusahaan semakin baik, karena return semakin besar

\section{Pembiayaan pada Bank Syariah}

Salah satu fungsi dan kegiatan bank syariah adalah menyalurkan dana dalam bentuk pembiayaan. Pembiayaan secara luas menurut Muhammad (2002) berarti financing atau pendanaan yang dikeluarkan untuk mendukung investasi yang telah direncanakan, baik dilakukan sendiri maupun dijalankan oleh orang lain.Alokasi dana dalam bentuk pembiayaanmenurut Muhammad (2002)mempunyai beberapa tujuan yaitu mencapai tingkat profitabilitas yang cukup dan tingkat resiko yang rendah, dan mempertahankan kepercayaan masyarakat dengan menjaga agar posisi likuiditas tetap aman.

Siamat (2005) menyatakan bahwa penyaluran pembiayaan merupakan kegiatan yang mendominasi pengalokasian dana bank. Penggunaan dana untuk penyaluran pembiayaan ini mencapai $70 \%$ sampai $80 \%$ dai volume usaha bank. Oleh karena itu, sumber utama pendapatan bank berasal dari kegiatan penyaluran pembiayaan baik dalam bentuk bagi hasil, mark up, maupun pendapatan sewa. Menurut Firdaus (2009), dengan diperolehnya pendapatan dari pembiayaan, maka diharapkan profitabilitas bank akan membaik yang tercermin dari perolehan laba yang meningkat.

Menurut Karim (2008), jenis-jenis pembiayaan syariah menurut tujuannya dibedakan menjadi pembiayaan modal kerja syariah, pembiayaan investasi syariah, dan pembiayaan konsumtif syariah. Akad atau prinsip yang menjadi dasar operasional bank syariah dalam menyalurkan pembiayaan menurut Karim (2008) dibedakan menjadi 4 macam yaitu prinsip jual beli (murabahah, salam dan istishna"), prinsip bagi hasil (mudharabah dan musyarakah), prinsip sewa (ijarah dan ijarah muntahhiyah bittamlik), serta akad pelengkap (hiwalah, rahn, qardh, wakalah, dan kafalah). Berdasarkan statistik Bank Indonesia, pola utama pembiyaan yang mendominasi pada bank syariah adalah prinsip jual beli dan prinsip bagi hasil.

Prinsip jual beli dilaksanakan sehubungan dengan adanya perpindahan kepemilikan barang atau benda. Tingkat keuntungan bank ditentukan di depan dan menjadi bagian atas harga barang yang dijual. Transaksi jual beli dapat dibedakan berdasarkan bentuk pembayarannya dan waktu penyerahanannya. Berdasarkan statistik Bank Indonesia bulan September tahun 2011, akad yang paling banyak digunakan pada prinsip jual beli adalah murabahah yaitu sekitar 54,98\% dari total pembiayaan yang diberikan bank syariah di Indonesia. Sedangkan pembiayaan salam dan istishna' hanya sebagian kecil yaitu 0,07\% dan $0,51 \%$ dari total pembiayaan.Karim (2008) menyatakan bahwa murabahahmerupakan transaksi jual beli di mana bank menyebut jumlah keuntungannya.Harga jual adalah harga beli bank dari pemasok ditambah keuntungan (margin).Sedangkan salam adalah transaksi jual beli di mana barang yang diperjualbelikan belum ada. Barang diserahkan secara tangguh sementara pembayaran dilakukan secara tunai. Dalam transaksi ini, kuantitas, kualitas, harga, dan waktu penyerahan barang harus ditentukan secara pasti.Untuk akadistishna" menyerupai 
produk salam, tetapi dalam istishna'pembayaran dapat dilakukan oleh bank dalam beberapa kali (termin) pembayaran. Melalui pembiayaan jual beli yang disalurkan, bank syariah akan mendapatkan pendapatan berupa mark upatau margin keuntungan.

Secara umum, prinsip bagi hasil dalam perbankan syariah dapat dilakukan dalam empat akad utama, yaitu: musyarakah, mudharabah, muzara'ah, dan musaqah. Meskipun demikian, prinsip yang paling banyak digunakan adalah musyarakahdan mudharabah(Antonio, 2001). Nurhayati dan Wasilah (2011) menyatakan bahwa secara teknis mudharabah adalah akad kerja sama usaha antara pemilik dana dan pengelola dana untuk melakukan kegiatan usaha, laba dibagi atas dasar nisbah bagi hasil menurut kesepakatan kedua belah pihak, sedangkan bila terjadi kerugian akan ditanggung oleh pemilik dana. Karim (2006) menyatakan bahwa musyarakah merupakan semua bentuk usaha yang melibatkan dua pihak atau lebih di mana mereka secara bersama-sama memadukan seluruh bentuk sumber daya baik yang berwujud maupun tidak berwujud. Keuntungan dan kerugian ditanggung bersama sesuai dengan proporsi yang telah ditetapkan sebelumnya. Melalui pembiayaan bagi hasil yang disalurkan, bank syariah akan memperoleh pendapatan berupa bagi hasil yang menjadi bagian bank.

Pembiayaan menurut kualitasnya pada hakikatnya didasarkan atas resiko kemungkinan terhadap kondisi dan kepatuhan nasabah pembiayaan dalam memenuhi kewajiban-kewajiban untuk membayar bagi hasil, serta melunasi pembiayaannya.Sehingga dapat menimbulkan pembiayaan bermasalah. Menurut Siamat (2005), pembiayaan bermasalah adalah pinjaman yang mengalami kesulitan pelunasan akibat adanya faktor kesengajaan dan atau karena faktor eksternal diluar kemampuan kendali nasabah peminjam.Non Performing Financing adalah rasio yang digunakan untuk mengukur kemampuan manajemen bank dalam mengelola pembiayaan bermasalah yang ada dapat dipenuhi dengan aktiva produktif yang dimiliki oleh suatu bank. (Teguh Pudjo Mulyono, 1995). Ali (2004) menyatakan bahwa apabila porsi pembiayaan bermasalah membesar maka hal tersebut pada akhirnya berpengaruh pula pada kemungkinan terjadinya penurunan besarnya keuntungan/pendapatan yang diperoleh bank.

\section{Perumusan Hipotesis}

Pembiayaan dengan prinsip jual beli pada bank syariah dilakukan melalui akad murabahah, salam dan istishna". Muhammad (2005) menyatakan bahwa salah satu akad dari pembiayaan jual beli yaitu akad murabahah merupakan produk yang paling populer dalam industri perbankan syariah. Hal tersebut dikarenakan beberapa alasan antara lain murabahah adalah suatu mekanisme investasi jangka pendek dan cukup memudahkan dibandingkan dengan sistem profit and loss sharing (PLS); mark up dalam murabahah dapat ditetapkan sedemikian rupa sehingga memastikan bahwa bank dapat memperoleh keuntungan yang sebanding dengan keuntungan bank-bank berbasis bunga yang menjadi saingan bank-bank Islam; murabahah menjauhkan ketidakpastian yang ada pada pendapatan dari bisnis-bisnis dengan sistem PLS; dan murabahah tidak memungkinkan bank-bank Islam untuk mencampuri manajemen bisnis karena bank bukanlah mitra nasabah, sebab hubungan mereka dalam murabahah adalah hubungan antara kreditur dan debitur.

Pengelolaan pembiayaan jual beli yang merupakan salah satu komponen penyusun aset terbesar pada perbankan syariah akan mengahasilkan pendapatan berupa margin/mark up. Dengan diperolehnya pendapatan mark up tersebut, maka akan mempengaruhi besarnya laba yang diperoleh bank syariah. Serta pada akhirnya mampu mempengaruhi peningkatan profitabilitas yang tercermin dari ROA (Return on Asset).

Bukti empiris dari Wicaksana (2011) menunjukkan bahwa semakin tinggi pembiayaan murabahah yang merupakan salah satu jenis pembiayaan jual beli, maka semakin tinggi profitabilitas bank umum syariah yang diproksikan denganReturn on Asset. Sedangkan bukti empiris dari Maya (2009) menunjukkan bahwa semakin tinggi pembiayaan murabahah yang merupakan salah satu jenis pembiayaan jual beli, maka semakin kecil profitabilitas 
bankumum syariah yang diproksikan dengan net profit margin dan gross profit margin. Berdasarkan kajian teori dan hasil penelitian terdahulu, maka dirumuskan hipotesis sebagai berikut:

\section{$H_{1}$ : Pembiayaan jual beli berpengaruh terhadap profitabilitas Bank Umum Syariah.}

Pembiayaan bagi hasil pada perbankan syariah dilakukan melalui akad mudharabah dan musyarakah. Pembiayaan bagi hasil merupakan salah satu komponen penyusun aset pada perbankan syariah. Dari pengelolaan pembiayaan bagi hasil, bank syariah memperoleh pendapatan bagi hasil sesuai dengan nisbah yang telah disepakati dengan nasabah (Muhammad, 2005). Pendapatan yang diperoleh akan mempengaruhi besarnya laba yang diperoleh bank (Firdaus, 2009). Besarnya laba yang diperoleh bank syariah akan mampu mempengaruhi profitabilitas yang dicapai.

Bukti empiris dari Wicaksana (2011) menunjukkan bahwa semakin tinggi pembiayaan mudharabah dan musyarakah maka semakin tinggi profitabilitas bank umum syariah yang diproksikan dengan Return on Asset. Sedangkan bukti empiris Maya (2009) menunjukkan bahwa semakin tinggi pembiayaan mudharabah dan musyarakah maka semakin rendah profitabilitas bank umum yang diproksikan dengan net profit margin dan gross profit margin. Berdasarkan kajian teori dan hasil penelitian terdahulu, maka dirumuskan hipotesis sebagai berikut:

\section{$\mathrm{H}_{2}$ : Pembiayaan bagi hasil berpengaruh terhadap profitabilitas Bank Umum Syariah.}

Non Performing Financing adalah rasio yang digunakan untuk mengukur kemampuan manajemen bank dalam mengelola pembiayaan bermasalah yang ada dapat dipenuhi dengan aktiva produktif yang dimiliki oleh suatu bank (Teguh Pudjo Mulyono, 1995). Ali (2004) menyatakan bahwa apabila porsi pembiayaan bermasalah membesar maka hal tersebut pada akhirnya berpengaruh pula pada kemungkinan terjadinya penurunan besarnya keuntungan/pendapatan yang diperoleh bank. Penurunan pendapatan ini akan mampu mempengaruhi besarnya perolehan laba bank syariah. Dan pada akhirnya, akan mempengaruhi besarnya profitabilitas yang tercermin denganReturn on Asset (ROA) yang diperoleh bank syariah.

Bukti empiris dari penelitian Santoro (2011) dan Nainggolan (2010), menunjukkan bahwa semakin tinggi rasio NPF maka akan semakin tinggi profitabilitas bank umum syariah yang diproksikan denganReturn on Asset. Sedangkan bukti empiris dari Adyani (2011) menunjukkan bahwa semakin tinggi rasio NPF maka akan semakin rendah profitabilitas bank umum syariah yang diproksikan denganReturn on Asset. Berdasarkan kajian teori dan hasil penelitian terdahulu, maka dirumuskan hipotesis sebagai berikut:

$\mathrm{H}_{3}$ : Non Performing Financing (NPF) berpengaruh tehadap profitabilitas Bank Umum Syariah.

\section{METODOLOGI PENELITIAN}

\section{Populasi dan Sampel Data}

Populasi yang menjadi objek dalam penelitian ini seluruh bank umum syariah yang ada di Indonesia. Penentuan sampel dilakukan secara nonrandom (nonprobability sampling) dengan metode purposive sampling yang dilakukan dengan mengambil sampel dari populasi berdasarkan suatu kriteria tertentu (Jogiyanto, 2004). Kriteria bank umum syariah yang menjadi sampel dalam penelitian ini adalah: (1) bank umum syariah yang secara rutin mempublikasikan laporan keuangan triwulanan selama periode pengamatan yaitu kuartal I tahun 2009 sampai dengan kuartal III tahun 2011; (2) bank umum syariah yang memiliki kelengkapan data berdasarkan variabel yang diteliti.Berdasarkan kriteria pemilihan sampel di 
atas, bank umum syariah yang memenuhi kriteria untuk menjadi sampel adalah empat bank umum syariah yaitu PT Bank Muamalat Indonesia, PT Bank Syariah Mandiri, PT Bank Syariah Mega Indonesiadan PT Bank Syariah BRI.Prosedur pemilihan sampel tersebut disajikan dalam tabel 1 sebagai berikut:

\section{Tabel 1}

\section{Prosedur Pemilihan Sampel}

\begin{tabular}{clc}
\hline No. & \multicolumn{1}{c}{ Keterangan } & Jumlah \\
\hline 1 & Jumlah Bank Umum Syariah di Indonesia pada tahun 2011 & 11 \\
\hline 2 & $\begin{array}{l}\text { Jumlah bank yang tidak memenuhi kriteria tersedianya data } \\
\text { triwulan I 2009 - triwulan II 2011 }\end{array}$ & (7) \\
\hline 3 & $\begin{array}{l}\text { Jumlah bank sesuai kriteria memenuhi data 2009-2011 dan } \\
\text { dijadikan sampel dalam penelitian ( 11 triwulan amatan) }\end{array}$ & 4 \\
\hline & $\begin{array}{l}\text { Total sampel yang digunakan (11 triwulan amatan data per } \\
\text { triwulan) }\end{array}$ & 4x11=44 \\
\hline
\end{tabular}

Sumber: Bank Indonesia 2011 (Data Sekunder Diolah)

\section{Data Penelitian}

Berdasarkan cara memperoleh data, jenis data dalam penelitian ini adalah data sekunder (secondary date). Menurut Sekaran (2006), data sekunder mengacu pada informasi yang dikumpulkan oleh seseorang dan bukan peneliti yang melakukan studi mutakhir. Data sekunder yang digunakan dalam penelitian ini merupakan data - data kuantitatif, meliputi laporan keuangan triwulanan bank umum syariah yang menjadi sampel selama periode triwulan I 2009 sampai triwulan III 2011. Data sekunder yang dibutuhkan tersebut diperoleh dari publikasi oleh instansi-instansi yang terkait seperti Bank Indonesia dan bank syariah yang dimaksud di sampel penelitian melalui browsing pada website instansi-instansi tersebut.

\section{Identifikasi Variabel Penelitian}

\section{Variabel Independen}

Variabel independen adalah variabel yang mempengaruhi atau yang menjadi sebab perubahannya atau timbulnya variabel dependen (Sugiyono, 2008). Variabel independen dalam penelitian ini adalah sebagai berikut:

\section{a. Pembiayaan jual beli}

Pembiayaan jual beli yang dimaksud di sini adalah pembiayaan yang disalurkan oleh bank syariah dengan prinsip murabahah, salam dan istishna'. Total pembiayaan jual beli diukur dengan logaritma natural dari nilai pembiayaan jual beli pada akhir tiap triwulan. Penggunaan logaritma natural bertujuan agar hasilnya tidak menimbulkan bias, mengingat besarnya nilai pembiayaan jual beli antar bank syariah yang berbeda-beda. Selain itu, dimaksudkan agar data total pembiayaan jual beli dapat terdistribusi normal dan memiliki standar eror koefisien regresi minimal (Theresia dan Tendelilin, 2007) dalam (Mulianti, 2010:60).

Total Pembiayaan jual beli $i_{, t}=$ Ln (Pembiayaan Prinsip Murabahah $_{i, t}+$ PembiayaanPrinsip Salam ${ }_{i, t}+$ Pembiayaan Prinsip Istishna $\left._{i, t}{ }^{\prime}\right)$

b. Pembiayaan bagi hasil

Pembiayaan bagi hasil yang dimaksud di sini adalah total pembiayaan bagi hasil yang disalurkan bank syariah, baik dengan prinsip mudharabah dan musyarakah. Total pembiayaan bagi hasil diukur dengan logaritma natural dari nilaipembiayaan bagi hasil pada akhir tiap triwulan. Penggunaan logaritma natural bertujuan agar hasilnya tidak menimbulkan bias, mengingat besarnya nilai pembiayaan bagi hasil antar bank syariah yang berbeda-beda. Selain itu, dimaksudkan agar data total pembiayaan bagi 
hasildapatterdistribusi normal dan memiliki standar eror koefisien regresi minimal (Theresia dan Tendelilin, 2007) dalam (Mulianti, 2010:60).

Total Pembiayaan bagi hasil ${ }_{i, t}=$ Ln (Pembiayaan Prinsip Mudharabah ${ }_{i, t}+$

c. Non Performing Financing (NPF)

PembiayaanPrinsipMusyarakah $_{i, t}$ )

Non Performing Financing adalah rasio yang digunakan untuk mengukur kemampuan manajemen bank dalam mengelola pembiayaan bermasalah yang ada dapat dipenuhi dengan aktiva produktif yang dimiliki oleh suatu bank. (Teguh Pudjo Mulyono, 1995). Berdasarkan Surat Edaran Bank Indonesia Nomor 12/11/DPNP tanggal 31 Maret 2010, pembiayaan dalam hal ini adalah pembiyaaan yang diberikan kepada pihak ketiga dan tidak termasuk pembiayaan kepada bank lain yang dihitung berdasarkan nilai tercatat dalam neraca per posisi tidak disetahunkan. Sedangkan pembiayaan bermasalah adalah kredit dengan kualitas kurang lancar, diragukan, dan macet yang dihitung berdasarkan nilai tercatat dalam neraca per posisi tidak disetahunkan.Rasio Non Performing Financing (NPF) dihitung dengan rumus sebagai berikut:

$$
N P F=\frac{\text { Pembiayaan Bermasalah }}{\text { Total Pembiayaan yang Disalurkan }}
$$

\section{Variabel Dependen}

Variabel dependen merupakan variabel yang dipengaruhi atau yang menjadi akibat, karena adanya variabel bebas (Sugiyono, 2008). Variabe dependen dalam penelitian ini adalah profitabilitas bank umum sayriah yang diproksikan denganReturn on Asset(ROA). ROA dipilih karena merupakan salah satu rasio profitabilitas yang digunakan untuk mengukur efektivitas perusahaan dalam menghasilkan keuntungan dengan memanfaatkan total aset yang dimilikinya. Perhitungan ROA berdasarkan Surat Edaran Bank Indonesia Nomor 12/11/DPNP tanggal 31 Maret 2010, diperoleh dengan rumus:

$$
\mathrm{ROA}=\frac{\text { Laba Sebelum Pajak Disetahunkan }}{\text { Rata }- \text { Rata Total Aset }}
$$

\section{Metode Analisis}

Analisis data dalam penelitian ini adalah analisis kuantitatif dengan menggunakan teknik perhitungan statistik. Analisis data yang diperoleh dalam penelitian ini akan menggunakan bantuan teknologi komputer yaitu microsoft excel dan menggunakan program aplikasi SPSS (Statistical and Service Solution). Metode analisis data yang digunakan dalam penelitian ini adalah dengan metode analisi Regresi Linier Berganda. Dalam melakukan analisis regresi linier berganda, metode ini mensyaratkan untuk melakukan uji asumsi klasik agar mendapatkan hasil regresi yang baik (Ghozali, 2009). Uji asumsi klasik tersebut terdiri dari: (1) uji non multikoliniearitas dengan menggunakan nilai Tolerance danVariance Inflation Factor (VIF); (2) ujinonautokorelasi dengan melakukan pengujian nilai Durbin Watson (DW test); (3) uji homoskedastisitasdengan menggunakan uji Glejser; dan (4) uji normalitasdengan menggunakan uji Kolmogrov-Smirnov dengan tingkat signifikansi $5 \%$.

Persamaan regresi berganda dalam penelitian ini sebagai berikut:

$\mathrm{ROA}=\alpha+\beta 1 \mathrm{Ln} \_\mathrm{PJB}+\beta 2 \mathrm{Ln} \_\mathrm{PBH}+\beta 3 \mathrm{NPF}+\varepsilon 1$

Keterangan:
A $\quad$ : Konstanta
$\beta 1, \beta 2, \beta 3, \beta 4:$ Koefisien regresi
ROA : Return on Asstes
PJB $\quad$ : Pembiayaan jual beli
PBH : Pembiayaan bagi hasil
NPF : Non Performing Financing
$\varepsilon 1 \quad$ : Error (kesalahan pengganggu) 
Ketepatan fungsi regresi sampel dalam menaksir nilai aktual dapat diukur dari goodness of fit. Secara statistik, goodness of fit dapat diukur dari nilai koefisien determinasi $\left(\mathrm{R}^{2}\right)$, nilai statistik F, dan nilai statistik $\mathrm{t}$ (Ghozali, 2009).

\section{ANALISIS DAN HASIL PENELITIAN Statistik Deskriptif}

Tabel 2 menyajikan ringkasan hasil analisis statistik deskriptif untuk keseluruhan variabel yang digunakan dalam penelitian ini.Berdasarkan Tabel 2, dapat dilihat bahwa nilai standar deviasi untuk keseluruhan variabel penelitian lebih rendah daripada nilai rata-ratanya. Hal ini menunjukkan bahwa nilai setiap variabel yang diteliti memiliki perbedaan yang relatif kecil antara masing-masing bank syariah yang menjadi sampel.

\section{Tabel 2}

Hasil Analisis Statistik Deskriptif

\begin{tabular}{|l|c|r|r|r|r|}
\hline Variabel & $\mathrm{N}$ & \multicolumn{1}{|c|}{ Minimum } & \multicolumn{1}{|c|}{ Maximum } & \multicolumn{1}{c|}{ Mean } & Std. Deviation \\
\hline ROA & 44 &, 00 &, 03 &, 0164 &, 00810 \\
PJB & 44 & 799998,00 & 17989739,00 & 5669157,8636 & 4093524,33422 \\
PBH & 44 & 119363,00 & 9891985,00 & 3919364,8864 & 3564297,35935 \\
NPF & 44 &, 01 &, 09 &, 0413 &, 01577 \\
Valid N & 44 & & & & \\
\hline
\end{tabular}

Sumber Data: Data sekunder yang diolah (Lihat Lampiran)

Berdasarkan Tabel 2, dapat diketahui bahwa rata-rata pembiayaan jual beli pada bank syariah lebih besar dibandingkan rata-rata pembiayaan jual beli. Hal ini menunjukkan bahwa proporsi penyaluran dana melalui pembiyaan jual beli secara umum lebih besar dibandingkan pembiyaan bagi hasil. Sedangkan nilai rata-rata NPF dari variabel yang diteliti adalah sebesar 0,0413 . Nilai tersebut berada di bawah 5\%, sehingga menujukkan bahwa secara umum bank syariah yang menjadi sampel masih dinilai sehat. Hal tersebut dikarenakan berdasarkan Peraturan Bank Indonesia Nomor 6/10/PBI/2004 tanggal 12 April 2004 tentang Sistem Penilaian Tingkat Kesehatan Bank Umum, semakin tinggi nilai NPF (diatas 5\%) maka bank tersebut tidak sehat.

\section{Uji Asumsi Klasik}

Tabel 3 merupakan ringkasan hasil pengujian asumsi klasik dari model yang dianalisis, yaitu uji non multikolinieritas, uji non autokorelasi, uji homoskedastisitas dan uji normalitas.

Tabel 3

Hasil Uji Asumsi Klasik

\begin{tabular}{|c|c|c|c|c|}
\hline \multirow[b]{2}{*}{ Variabel } & \multicolumn{2}{|c|}{ Multikolinieritas } & \multicolumn{2}{|c|}{ Homoskedastisitas } \\
\hline & Tolerance & VIF & Stat. $\mathrm{t}$ & Sig \\
\hline PJB & 0,264 & 3,793 & $-0,816$ & 0,419 \\
\hline PBH & 0,236 & 4,241 & $-0,546$ & 0,588 \\
\hline NPF & 0,655 & 1,527 & 1,051 & 0,299 \\
\hline \multicolumn{5}{|l|}{ Normalitas } \\
\hline Kolmogrov-Sminorv & \multicolumn{2}{|c|}{0,646} & & \\
\hline Asymp. Sig & \multicolumn{2}{|c|}{0,797} & & \\
\hline \multicolumn{5}{|l|}{ Autokorelasi } \\
\hline Durbin-Watson & \multicolumn{2}{|c|}{1,578} & & \\
\hline
\end{tabular}


Sumber Data: Data sekunder yang diolah (Lihat Lampiran)

Uji non multikolinieritas bertujuan untuk menguji apakah dalam model regresi ditemukan adanya korelasi antar varibel independen. Model regresi yang baik adalah tidak terjadi korelasi yang tinggi diantara variabel independennya. Uji non multikoliniearitas dalam penelitian ini menggunakan nilai Tolerance dan Variance Inflation Factor (VIF). Nilai cutoff yang umum dipakai untuk menunjukkan adanya multikoliniearitas adalah nilai Tolerance $\leq$ 0,10 atau nilai VIF $\geq 10$, maka diindikasikan model regresi memiliki gejala multikoliniearitas.Berdasarkan hasil perhitungan pada tabel 3menunjukkan bahwa tidak ada variabel independen yang memilki nilai VIF lebih besar dari 10. Selain itu, hasil perhitungan juga menunjukkan tidak ada variabel independen yang memiliki nilai tolerance kurang dari 0,10 yang berarti tidak ada korelasi antar variabel independen yang nilainya lebih dari 95\%.Oleh karena itu, dapat disimpulkan bahwa variabel independen yang digunakan dalam model regresi penelitian ini terbebas dari masalah multikolinieritas.

Uji non autokorelasibertujuan untuk menguji apakah model regresi linier ada korelasi antara kesalahan penggganngu pada periode $t$ dengan kesalahan pengganggu pada periode $\mathrm{t}-1$ (sebelumnya).Dari hasil perhitungan pada tabel 3, diperoleh nilai DW sebesar 1,578, nilai ini akan dibandingkan dengan nilai tabel dengan menggunakan nilai signifikansi 5\%, jumlah sampel 44 dan jumlah variabel independen 3. Maka pada tabel Durbin-Watson diperoleh nilai $\mathrm{d}_{\mathrm{U}}$ (batas atas) sebesar 1,615 dan nilai $\mathrm{d}_{\mathrm{L}}$ (batas bawah) sebesar 1,383. Oleh karena 1,615 $\left(\mathrm{d}_{\mathrm{U}}\right)$ $\leq 1,578(\mathrm{DW}) \leq 1,383\left(\mathrm{~d}_{\mathrm{L}}\right)$, maka diperoleh kesimpulan bahwa tidak ada keputusan untuk menolak atau menerima $\mathrm{H}_{0}$ yang menyatakan bahwa tidak ada autokorelasi.

Uji homoskedastisitas bertujuan untuk menguji apakah dalam model regresi terjadi ketidaksamaan variance dari residual satu pengamatan ke pengamatan lain. Jika variance dari residual satu pengamatan ke pengamatan lain tetap, maka disebut homokesdastisitas dan jika berbeda disebut heterokedastisitas. Model regresi yang baik adalah yang homokesdastisitas atau tidak terjadi heterokedastisitas.Penelitian ini menggunakan uji Glejser untuk mendeteksi ada tidaknya heterokedastisitas.Berdasarkan tabel 3 menunjukkan bahwa tidak ada satupun variabel independen yang signifikan secara statistik mempengaruhi variabel dependen nilai Absolut Ut (AbsUt). Hal ini terlihat dari probabilitas signifikansinya di atas tingkat kepercayaan 5\%. Sehingga dapat disimpulkan model regresi terbebas dari masalah heteroskedastisitas.

Uji normalitas bertujuan untuk menguji apakah dalam model regresi, variabel penganggu atau residual memiliki distribusi normal. Model regresi yang baik adalah memiliki distribusi data normal atau mendekati normal. Alat uji yang digunakan pada penelitian ini adalah uji statistik dengan Kolmogrov-Smirnov Z (I-Sample K-S).Dari tabel 3 diketahui bahwa besarnya nilai Asymp.sig adalah 0,797. Nilai tersebut lebih dari 5\% . Sehingga dapat disimpulkan bahwa data residual berdistribusi normal.

\section{Hasil Uji Hipotesis}

Tabel 4 menyajikan hasil uji hipotesis.Berdasarkan hasil yang diperoleh pada tabel 4 , diperoleh nilai Adjusted $R$ Square sebesar 0,249 atau 24,9\%. Hal ini berarti sebesar 24,9\% variasi ROA dapat dijelaskan oleh variasi dari tiga variabel independen yaitu pembiayaan jual beli, pembiayaan bagi hasil dan NPF. Sedangkan sisanya yaitu sebesar 75,1\% dijelaskan oleh sebab-sebab lain diluar model yang diteliti.Selanjutnya, berdasarkan uji statistik F pada Tabel 4, diketahui bahwa nilai $\mathrm{F}$ hitung sebesar 5,741 dengan nilai signifikansi sebesar 0,2\%. Nilai signifikansi tersebut lebih kecil dari $\alpha(5 \%)$. Hal tersebut berarti model regresi dapat digunakan untuk memprediksi nilai ROA (Return on Asset). Sehingga dapat disimpulkan bahwa variabel pembiayaan jual beli, pembiayaan bagi hasil dan NPF (Non Performing Financing) secara bersama-sama (simultan) berpengaruh secara signifikan terhadap variabel ROA (Return on Asset). 
Tabel 4

Hasil Uji Hipotesis

\begin{tabular}{|l|l|l|l|l|}
\hline Variabel & Cefficient & Standar Error & t-Statistic & Sig. \\
\hline (Constaant) & $-0,165$ & 0,058 & $-2,844$ & 0,007 \\
Ln_PJB & 0,011 & 0,003 & 3,672 & 0,001 \\
Ln_PBH & $-0,005$ & 0,001 & $-3,814$ & 0,000 \\
NPF & 0,285 & 0,084 & 3,397 & 0,002 \\
\hline R-Square & \multicolumn{3}{|c|}{0,301} \\
Adjusted R Square & \multicolumn{3}{|c|}{0,249} \\
F-Statistic & 5,741 & \\
Sig. (F Statistic) & 0,002 & \\
\hline
\end{tabular}

Berdasarkan tabel 4, dapat diketahui bahwa untuk uji t, semua variabel independen memiliki nilai signifikansi di bawah $\alpha(5 \%)$. Hal tersebut menunjukkan bahwa penelitian ini mampu mendukung hipotesis satu yang menyatakan bahwa variabel pembiayaan jual beli memberikan pengaruh signifikan terhadap profitabilitas yang diproksikan dengan ROA.Hasil empiris ini konsisten dengan hasil penelitian Wicaksana (2011), tetapi tidak konsisten dengan hasil penelitian Maya (2009).

Penelitian ini juga berhasil mendukung hipotesis kedua yang menyatakan bahwa variabel pembiayaan bagi hasil memberikan pengaruh signifikan terhadap profitabilitas yang diproksikan dengan ROA.Hasil empiris ini konsisten dengan hasil penelitian Maya (2009), tetapi tidak konsisten dengan hasil penelitian Wicaksana (2011).

Penelitian ini juga mampu mendukung hipotesis ketiga yang menyatakan bahwa variabel NPF (Non Performing Financing) memberikan pengaruh signifikan terhadap profitabilitas yang diproksikan dengan ROA.Hasil empiris ini konsisten dengan hasil penelitian Santoro (2010) dan Nainggolan (2010), tetapi tidak konsisten dengan hasil penelitian Adyani (2011).

\section{Diskusi Hasil Penelitian}

Hasil pengujian menunjukkan bahwa pembiayaan jual beli berpengaruh positif signifikan terhadap ROA (Return on Asset). Hal ini berarti bahwa peningkatan jumlah pembiayaan jual beli yang disalurkan bank syariah akan berpengaruh dalam meningkatkan ROA (Return on Asset). Hasil penelitian ini sejalan dengan penelitian Wicaksana (2011), tetapi tidak sesuai dengan hasil penelitian Maya (2009).

Bank syariah pada umumnya telah menggunakan murabahah sebagai metode pembiayaan utama, meliputi kira-kira tujuh puluh lima persen dari total kekayaan mereka (Muhammad, 2005). Hasil penelitian ini menunjukkan bahwa pembiayaan jual beli yang merupakan pola pembiayaan terbesar yang selama ini disalurkan bank umum syariah, serta didominasi oleh prinsip murabahah dan disusul oleh prinsip salam dan istishna" mampu memberikan pengaruhi yang positif tingkat profitabilitas bank umum syariah yang diukur dengan ROA. Pendapatan mark up yang diperoleh bank umum syariah masih merupakan pendapatan terbesar bagi bank umum syariah. Pendapatan mark up ini mampu meningkatkan laba dan pada akhirnya mampu meningkatkan profitabilitas yang diukur dengan ROA.Pengaruh positif pembiayaan jual beli terhadap ROA juga menunjukkan bahwa pengelolaan pembiayaan jual beli yang merupakan salah satu komponen aset bank umum syariah telah dilakukan dengan baik. Sehingga mampu menghasilkan laba yang optimal bagi bank umum syariah.

Pada umumnya pembiayaan jual beli yang didominasi oleh produk murabahah pada bank umum syariah lebih populer dan mudah pengelolaannya dibandingkan sistem bagi hasil. Muhammad (2005) menyatakan bahwa murabahah adalah suatu mekanisme ivestasi jangka pendek dan cukup memudahkan dibandingkan dengan sistem bagi hasil; mark up dalam murabahah dapat ditetapkan sedemikian rupa sehingga memastikan bahwa bank dapat 
memperoleh keuntungan yang sebanding dengan keuntungan bank-bank berbasis bunga yang menjadi saingan bank-bank Islam; murabahah menjauhkan ketidakpastian yang ada pada pendapatan dari bisnis-bisnis dengan sistem bagi hasil; dan murabahah tidak memungkinkan bank-bank Islam untuk mencampuri manajemen bisnis karena bank bukanlah mitra nasabah, sebab hubungan mereka dalam murabahah adalah hubungan antara kreditur dan debitur. Selain itu, Muhammad (2005) juga menyatakan bahwa bank-bank Islam secara efektif menghilangkan risiko dalam pelaksanaan murabahah. Murabahah merupakan metode paling dominan dalam menginvestasikan dana dalam perbankan Islam dan untuk tujuan-tujuan praktis, benar-benar model investasi yang bebas risiko, memberikan keuntungan yang ditetapkan di muka kepada bank atas modalnya. Laporan Council of Islamic Ideology dalam Muhammad (2005) mengemukakan bahwa dalam murabahah terdapat kemungkinan untuk mendapatkan laba bagi bank tanpa risiko kemungkinan rugi yang harus dibagi, kecuali dalam kebangkrutan atau kegagalan di pihak pembeli. Sedangkan untuk pembiayaan dengan akad salam dan istishna", Karim (2008) menyatakan bahwa risiko pembiayaan salam dan istishna' risiko gagal-serah barang yang dapat diantisipasi bank dengan menetakan konvenan rasio kolateral $220 \%$, yaitu $100 \%$ lebih tinggi daripada rasio standar $120 \%$, serta risiko jatuhnya harga barang yang diantisipasi dengan menetapkan bahwa jenis pembiayaan ini hanya dilakukan atas dasar kontrak (pesanan) yang telah ditentukan harganya.

Risiko yang rendah dari pembiayaan jual beli memungkinkan bank untuk lebih mudah mengelola pembiayaan dengan prinsip jual beli baik melalui akad murabahah, salam maupun istishna". Pengelolaan yang mudah ini, memungkinkan bank syariah untuk meningkatkan kemampuannya dalam mengahasilkan laba melalui pendapatan mark up yang bersumber dari pembiayaann jual beli yang disalurkannya kepada masyarakat. Sehingga peningkatan jumlah pembiyaan jual beli yang disalurkan kepada masyarakat akan berpengaruh dalam meningkatkan profitabilitas bank umum syariah yang dalam hal ini diukur dengan ROA (Return on Asset).

Hasil pengujian juga menunjukkan bahwa pembiayaan bagi hasil berpengaruhnegatif signifikan terhadap ROA (Return on Asset). Hal ini berarti bahwa peningkatan jumlah pembiyaan jual beli akan menurunkan nilai ROA. Hasil penelitian ini konsisten dengan hasil penelitian Maya (2009), tetapi tidak sesuai dengan hasil penelitian Wicaksana (2011).

Muhammad (2005) menyatakan bahwa dalam praktiknya, ternyata signifikansi bagi hasil dalam memainkan operasional investasi dana bank peranannya sangat lemah. Saeed (2003) dalam Muhammad (2005) mengemukakan bahwa menurut beberapa pengamatan perbankan syariah, lemahnya peranan bagi hasil dalam memeainkan operasional investasi dana bank dikarenakan beberapa alasan antara lain: pertama, terdapat anggapan bahwa standar moral yang berkembang di kebanyakan komunitas muslim tidak memberi kebebasan penggunaan bagi hasil sebagai mekanisme investasi. Sehingga mendorong bank untuk mengadakan pemantauan lebih intensif terhadap setiap investasi yang diberikan. Hal ini membuat operasional perbankan berjalan tidak ekonomi dan tidak efisien. Kedua, keterkaitan bank dalam pembiayaan sistem bagi hasil untuk membantu perkembangan usaha lebih banyak melibatkan pengusaha secara langsung daripada sistem lainnya pada bank konvensional. Besar kemungkinan pihak bank turut mempengaruhi setiap pengambilan keputusan bisnis mitranya. Pada sisi lain, keterlibatan yang tinggi ini akan mengecilkan naluri pengusaha yang sebenarnya lebih menuntut kebebasan yang luas daripada campur tangan dalam penggunaan dana yang dipinjamkan. Ketiga, pemberian pembiayaan berdasarkan sistem bagi hasil memerlukan kewaspadaaan yang lebih tinggi dari pihak bank. Bank syariah kemungkinan besar meningkatkan kualitas pegawainya dengan cara mempekerjakan para teknisi dan ahli manajemen untuk mengevaluasi proyek usaha yang dipinjami untuk mencermati lebih teliti dan lebih jeli daripada teknis peminjaman pada bank konvensional. Hal ini akan meningkatkan biaya yang dikeluarkan oleh para banker dalam menjaga efisiensi kinerja perbankannya. Serta yang terakhir, pada pemberian pembiayaan dengan sistem bagi hasil, apabila terjadi kerugian maka bank akan ikut menanggung kerugian bisnis yang dijalankan 
pengusaha. Kesanggupan untuk turut menanggung risiko ini, kemungkinan akan mendorong investasi lebih berisiko.

Dari penjelasan di atas, dapat disimpulkan bahwa pengelolaan pembiayaan bagi hasil yang merupakan salah satu komponen aset bank syariah lebih sulit daripada jenis pembiayaan lainnya. Biaya yang dikeluarkan dalam pengelolaan pembiayaan bagi hasil juga lebih tinggi daripada jenis pembiayaan lainnya. Pendapatan bagi hasil bank umum syariah yang diperoleh dari penyaluran pembiayaan bagi hasil kemungkinan masih belum secara optimal diperoleh sehingga belum mampu mengimbangi biaya-biaya yang dikeluarkan. Oleh karena itu, sumbangan pendapatan bagi hasil yang diperoleh dari penyaluran pembiayaan bagi hasil masih belum mampu mengoptimalkan kemampuan bank umum syariah dalam menghasilkan laba. Sehingga pada akhirnya justru berdampak pada penurunan ROA bank umum syariah. Jadi, walaupun rata-rata pembiyaan bagi hasil yang disalurkan oleh bank syariah terus mengalami peningkatan dari tahun ke tahun, bank syariah masih belum mampu mengelola pembiayaan bagi hasilnya dengan baik agar dapat memperoleh laba optimal. Hal ini terbukti oleh hasil penelitian yang menyimpulkan bahwa pembiayaan bagi hasil berpengaruh negatif terhadap profitabilitas bank umum syariah yang diukur dengan ROA.

Hasil penelitian yang menunjukkan bahwa pembiayaan bagi hasil berpengaruh signifikan negatif terhadap ROA juga semakin menguatkan kondisi pembiayaan bagi hasil yang masih kurang menarik dan kurang diminati oleh perbankan syariah di Indonesia. Berdasarkan data perbankan syariah pada statistik Bank Indonesia, sampai bulan September tahun 2011, porsi pembiayaan bagi hasil sebesar 29,51\% dari total pembiayaan yang disalurkan, sedangkan pembiayaan jual beli mencapai 54,09\% dari total pembiayaan yang disalurkan. Data tersebut memperlihatkan bahwa porsi pembiayaan bagi hasil masih berada jauh di bawah pembiayaan jual beli. Pembiayaan bagi hasil masih kurang diminati dibandingkan pembiyaan jual beli dikarenakan risiko pembiayaan bagi hasil yang lebih besar dibandingkan pembiayaan jual beli.

Hasil pengujian hipotesis ketiga menunjukkan bahwa rasioNPF (Non Performing Financing) berpengaruh positif signifikan terhadap ROA (Return on Asset). Hal ini berarti bahwa peningkatan NPF akan meningkatkan nilai ROA. Hasil penelitian ini sesuai dengan hasil penelitian Santoro (2010) dan Nainggolan(2010), tetapi tidak sesuai dengan hasil penelitian Adyani (2011).

Pengaruh positif NPF terhadap ROA disebabkan besarnya rata-rata NPFpada bank umum syariahyang menjadi sampel sebesar $4,13 \%$, masih berada di bawah $5 \%$. Berdasarkan Peraturan Bank Indonesia Nomor 6/10/PBI/2004 tanggal 12 April 2004 tentang Sistem Penilaian Tingkat Kesehatan Bank Umum, semakin tinggi nilai NPF (diatas 5\%) maka bank tersebut tidak sehat. Jadi apabila nilai NPF masih berada di bawah 5\%, maka bank masih dianggap sehat.

Berdasarkan statistik Bank Indonesia, rata-rata penyaluran dana berupa pembiayaan selama tahun 2009 sampai September 2011 adalah sebesar 74,47\%. Sedangkan sisanya disalurkan melalui penemapatan di bank lain, penempatan di Bank Indonesia, investasi surat berharga dan penyertaan. Proporsi pernyaluran dana pada bank syariah disajikan pada tabel 5 sebagai berikut:

Tabel 5

Proporsi Penyaluran Dana Bank Umum Syariah

\begin{tabular}{|l|l|l|l|}
\hline \multicolumn{1}{|c|}{ Keterangan } & \multicolumn{1}{c|}{$\mathbf{2 0 0 9}$} & \multicolumn{1}{c|}{ 2010 } & \multicolumn{1}{c|}{ Sept-2011 } \\
\hline Pembiayaan & 46.886 milyar & 68.181 milyar & 92.839 milyar \\
\hline Penempatan pada BI & 10.393 milyar & 16.393 milyar & 16.148 milyar \\
\hline $\begin{array}{l}\text { Penempatan pada Bank } \\
\text { lain }\end{array}$ & 3.036 milyar & 4.138 milyar & 3.716 milyar \\
\hline $\begin{array}{l}\text { Surat Berharga yang } \\
\text { Dimiliki }\end{array}$ & 3.786 milyar & 5.733 milyar & 5.924 milyar \\
\hline Penyertaan & 83 milyar & 88 milyar & 47 milyar \\
\hline
\end{tabular}


Dari penyaluran dana selain pembiayaan, bank akan memperoleh pendapatan yang dapat meningkatkan laba. Muhammad (2005) meyatakan bahwa dari penempatan pada bank lain atau Bank Indonesia, bank syariah akan mendapatkan pendapatan bagi hasil jika penempatan dananya dalam bentuk mudharabah. Sedangkan penyertaan modal sementara yang dilakukan Bank Syariah dalam perusahaan, untuk mengatasi kegagalan pembiayaan atau piutang. Siamat (2005) menyatakan bahwa penanaman dana dalam surat berharga dimaksudkan untuk mempertinggi profitabilitas bank. Jadi, apabila NPF mengalamikenaikan, return tetap akan naik karena ada penerimaan dari penempatan dana pada bank lain, penyertaan maupun investasi surat-surat berharga.Sehingga NPF seolah-olah berpengaruh positif tehadap ROA.

Akan tetapi, bank umum syariah harus tetap waspada pada tingkat NPF yang mengalami peningkatan. Hal tersebut dikarenakan, pada titik peningkatan tertentu di atas 5\% kemungkinan return dari penyaluran dana selain pembiyaan tidak akan mampu menutupi kerugian yang terjadi atas pembiyaan bermasalah. Oleh karena itu, bank syariah harus lebih berhati-hati dalam mengelola dan menyalurkan pembiayaan untuk mengurangi jumlah pembiayaan yang bermasalah.

\section{KESIMPULAN DAN IMPLIKASI}

Penelitian ini bertujuan untuk mengetahui tingkat signifikansi pengaruh pembiayaan jual beli, pembiayaan bagi hasil dan rasio Non Performing Financing (NPF) terhadap profitabilitas yang diproksikan dengan Return on Asset (ROA) pada bank umum syariah yang beroperasi di Indonesia periode Januari 2009 sampai September 2011, baik secara parsial maupun simultan. Penelitian ini menggunakan analisis regresi linier berganda dalam menganalisis data.Hasil pengujian menunjukkan bahwa secara simultan pembiayaan jual beli, pembiayaan bagi hasil dan rasio NPF berpengaruh signifikan terhadap profitabilitas yang diproksikan melalui ROA.

Secara parsial, pembiayaan jual belidan rasio NPF berpengaruh signifikan positif terhadap profitabilitas yang diproksikan melaluiReturn on Asset(ROA) pada bank umum syariah di Indonesia. Pengaruh positf pembiayaan jual beli terhadap profitabilitas ini terjadi karena selama ini pembiayaan bagi hasil merupakan jenis pembiyaan yang paling populer pada perbankan syariah. Sehingga pendapatan mark up yang diperoleh dari pembiyaan jual beli menjadi pendapatan terbesar perbankan syariah, yang pada akhirnya mampu meningkatkan profitabilitas.Untuk rasio NPF seharusnya memberikan pengaruh negatif terhadap profitabilitas. Akan tetapi, hasil penelitian ini menunjukkan bahwa rasio NPF justru berpengaruh positif terhadap ROA.Kemungkinan penjelasan yang dapat diberikan adalah return dari penyaluran dana selain pembiyaan seperti penempatan pada bank lain, investasi surat berharga, atau penyertaan mampu menutupi kerugian yang terjadi atas pembiyaan bermasalah, sehingga NPF seolah-olah berpengaruh positif tehadap ROA.Hasil penelitian ini juga menunjukkan bahwapembiayaan bagi hasil berpengaruh signifikan negatif terhadapprofitabilitas yang diproksikan melaluiReturn on Asset(ROA) pada bank umum syariah di Indonesia.Pembiayaan bagi hasilseharusnya diharapkan dapat meningkatkan profitabilitas bank syariah. Berpengaruh negatifnya pembiayaan bagi hasil ini mengindikasikan bahwa pembiyaan bagi hasil yang disalurkan masih belum produktif serta masih kurang diminatinya pembiayaan bagi hasil pada perbankan syariah.

Beberapa saran yang diajukan sehubungan dengan penelitian ini antara lain: (1) bank syariah harus tetap meningkatkan jumlah pembiayaan jual beliyang disalurkandan mengelolanya dengan baik agar pembiyaan yang dihasilkan bisa tetap produktif dan mampu meningkatkan profitabilitas; (2) produktifitas pembiyaan bagi hasil perlu ditingkatkan melalui penerapan kelayakan pembiyaan yang lebih ketat serta monitoring yang lebih akurat, bank syariah juga harus lebih berinovasi dalam menyalurkan pembiayaan bagi hasil agar pembiyaan bagi hasil bisa lebih menarik; (3) penyaluran dana selain pembiyaan perlu tetap 
dijaga agar bank syariah mampu memperoleh return yang mampu menutupi kerugian dari pembiyaan bermasalah, tetapi nilai NPF harus tetap dijaga di bawah 5\%dengan lebih berhatihati dalam menyalurkan pembiyaan agar kondisi bank tetap sehat.

Penelitian ini memiliki keterbatasan mengenai jumlah sampel yang kecil, laporan keuangan yang menjadi sumber data belum diaudit, sertatidak meneliti pengaruh setiap akad pembiayaan secara individu terhadap profitabilitas yang diproksikan dengan ROA, serta faktor-faktor lain yang juga mungkin berpengaruh.Bagi peneliti selanjutnya diharapkan dapat meneliti pengaruh setiap jenis akad pembiayaan dan ditambahkan dengan faktor-faktor lain yang kemungkinan berpengaruh terhadap ROA. Selain itu, diharapkan peneliti selanjutnya dapat menggunakan laporan keuangan yang sudah diaudit sebagai sumber datanya, serta dapat memperluas jumlah sampel penelitian. 


\section{DAFTAR PUSTAKA}

Adyani , Lyla Rahma. 2011. Analisis Faktor-Faktor Yang Mempengaruhi Profitabilitas (ROA) (Studi Pada Bank Umum Syariah Yang Terdaftar Di Bei Periode Desember 2005September 2010).Skripsi. Semarang: Jurusan Manajemen Fakultas Ekonomi Universitas Diponegoro.

Algaoud, Latifa M. dan Mervyn K. Lewis. 2005. Perbankan Syariah: Prinsip, Praktik dan Prosepek. Jakarta: PT Serambi Ilmu Semesta.

Ali, H. Masyhud. 2004. Asset Liability Management. Jakarta: PT Elex Media Komputindo.

Antonio, Muhammad Syafi'i, 2005. Bank Syariah, Dari Teori ke Praktek. Gema Insani Press: Jakarta.

Benget, M Nainggolan. 2010.Pengaruh Capital Adequacy Ratio, Non Performing Loan, Operational Efficiency Ratio, FinancingTo Deposit Ratio Terhadap Return On Asset Bank Mega Syariah Indonesia. Skripsi Jurusan Manajemen, Fakultas Ekonomi, Universitas Sumatera Utara.

Bank Indonesia. 1998.Undang-Undang Nomor 10 Tahun 1998 tentang Perubahan Atas Undang-Undang Nomor 7 Tahun 1992 Tentang Perbankan. Jakarta: Bank Indonesia.(http://www.bi.go.id, diakses 9 Oktober 2011)

Bank Indonesia. 2004. Peraturan Bank Indonesia Nomor 6/10/PBI/2004.Jakarta: Bank Indonesia.(http://www.bi.go.id, diakses 9 Oktober 2011)

Bank Indonesia. 2006. Peraturan Bank Indonesia Nomor 8/21/PBI/2006. Jakarta: Bank Indonesia.(http://www.bi.go.id, diakses 9 Oktober 2011)

Bank Indonesia. 2008.Undang-Undang Nomor 21 Tahun 2008 Tentang Perbankan Syariah. Jakarta: Bank Indonesia.(http://www.bi.go.id, diakses 9 Oktober 2011)

Bank Indonesia. 2011.Statistik Bank Indonesia September 2011. Jakarta: Bank Indonesia.(http://www.bi.go.id, diakses 9 Oktober 2011)

Bank Indonesia.2011. Outlook Perbankan Indonesia tahun 2011. Jakarta: Bank Indonesia.(http://www.bi.go.id, diakses 9 Oktober 2011)

Bank Muamalat Indonesia. Laporan Pubilkasi Triwulanan. Jakarta: Bank Muamalat Indonesia. (http://www.muamalatbank.com,diakses 11 November 2011)

Bank Rakyat Indonesia Syariah. Laporan Pubilkasi Triwulanan. Jakarta: Bank Rakyat Indonesia Syariah. (http://www.brisyariah.co.id, diakses 11 November 2011)

Bank Syariah Mandiri. Laporan Pubilkasi Triwulanan. Jakarta: Bank Syariah Mandiri. (http://www.syariahmandiri.co.id, diakses 11 November 2011)

Bank Syariah Mega Indonesia. Laporan Pubilkasi Triwulanan. Jakarta: Bank Syariah Mega Indonesia. (http://www.bsmi.co.id, diakses 11 November 2011)

Dody, Yoga Prasetyo Santoro. 2011. Analisis Pengaruh Beberapa Rasio Keuangan Terhadap Kinerja Profitabilitas Pada Bank Umum Syariah di Indonesia Periode 2006 - 2009. Skripsi Jurusan Akuntansi, Fakultas Ekonomi, Universitas Pembangunan Nasional Veteran.

Donald E. Kieso, Jerry J. Weygandt, Terry D. Warfield. 2002. Akuntansi Intermediate Edisi Kesepuluh. Jakarta: Erlangga.

Firdaus, H Rachmat \& Maya Ariyanti. 2009. Manajemen Perkreditan Bank Umum. Bandung: Alfabetta.

Ghozali, Imam, 2009. Aplikasi Analisis Multivariate dengan Program SPSS. Semarang: Badan Penerbit Universitas Diponegoro. 
Harahap, Sofyan S. Wiroso dan Muhammad Yusuf. 2005. Akuntansi Perbankan Syariah. Jakarta: LPFE- Usakti.

Jogiyanto. 2004. Metpen Salah Kaprah dan Pengalaman-Pengalaman. Yogyakarta: BPFE.

Karim, Adiwarman A. 2008. Bank Islam: Analisis Fiqih dan Keuangan Edisi 3. Jakarta: PT Raja Grafindo Persada.

Kuncoro, Mudrajad dan Suhardjono. 2002. Manajemen Perbankan Teori dan Aplikasi. Yogyakarta: Penerbit BPFE.

Maya, Puspa Pesona Putri. 2009. Analisis Pembiayaan Mudharabah, Musyarakah, dan Murabahah Hubungannya dengan Profitabilitas Bank Umum Syariah Periode 2003 2007. Skripsi Jurusan Manajemen, Fakultas Ekonomi, Universitas Islam Negeri Malang.

Muhamad. 2000. Lembaga-Lembaga Keuangan Umat Kontemporer. Yogyakarta: UII Press.

Muhammad. 2002. Bank Syariah Analisis Kekuatan, Kelemahan, Peluang dan Ancaman. Yogyakarta: Ekonosia.

Muhammad. 2005. Manajemen Pembiayaan Bank Syariah. Yogyakarta: UPP AMP YKPN.

Muhammad, \& Dwi Suwikayo. 2009. Akuntansi Perbankan Syariah. Yogyakarta: Trust Media.

Mulianti. 2010. Analisis Faktor-Faktor yang Mempengaruhi Kebijakan Hutang dan Pengaruhnya terhadap Nilai Perusahaan. Tesis. Semarang: Program Pascasarjana Universitas Diponegoro.

Nurhayati, Sri dan Wasilah. 2011. Akuntansi Syariah di Indonesia. Jakarta: Salemba Empat.

Sekaran, Uma. 2003. Research Methods for Business. Jakarta: Salemba Empat.

Siamat, Dahlan. 2005. Manajemen Lembaga Keuangan Edisi Kelima. Jakarta: Lembaga Penerbit FE UI.

Sugiyono. 2008. Metode Penelitian Kuantitatif Kualitatif dan R\&D. Bandung:CV Alfabeta

Teguh Pudjo Mulyo. 2000. Analisis Laporan Keuangan Perbankan. Jakarta: Djambatan

Wicaksana, Dwi Fany. 2011. Pengaruh Pembiayaan Mudharabah, Musyarakah dan MurabahahTerhadapProfitabilitasBank Umum Syariah di Indonesia.Skripsi. Malang: Jurusan Akuntansi Fakultas Ekonomi Universitas Negeri Malang.

Wiroso. 2005. Penghimpunan Dana dan Distribusi Hasil Usaha Bank Syariah. Jakarta: Grasindo. 